\title{
Analysis of the Determinants of Innovation in Developing Countries: A Vector Auto-regression Approach
}

\author{
${ }^{1}$ Benjamin Azembila Asunka, ${ }^{2}$ Zhiqiang Ma ${ }^{*}{ }^{3}$ Mingxing Li1, ${ }^{4}$ Oswin Agandaa Anaba, \\ ${ }^{1,2,3,4}$ School of Management, Jiangsu University, Zhenjiang 212013, China. \\ ${ }^{1}$ School of Business and Management, Bolgatanga Polytechnic, Bolgatanga \\ ${ }^{4}$ Department of Liberal Studies, Bolgatanga Polytechnic, Bolgatanga
}

\begin{abstract}
Several factors account for innovation output in developed economies as documented in extant literature. The objective of this study is to make a case for a multi-faceted approach to innovation in developing countries. To analyze various factors affecting innovation, a sample of 43 developing countries is taken and the period of study is between 2009 and 2018. A vector auto-regression model is used in a panel data setting to test the effect of various variables on innovation at country level, a granger causality test is also conducted to determine the causal relationship among these factors that together can spur innovation activities. Findings suggest a strong influence of R\&D and government procurement of technology on the advancement of innovation. R\&D is largely affected by the quality of research institutions and universityindustry collaborative research, thus showing the strength of the effect of these variables on innovation. Scientists and engineers with requisite expertise greatly improve a country's innovation efforts, however, developing countries do not benefit fully from the economic value of these experts. These results show that an integration of all these factors is a good approach to enhancing innovation in developing economies.
\end{abstract}

Keywords: Global competitiveness report; Innovation; R\&D; Panel vector auto-regression; Developing countries.

\section{Introduction}

Innovation has been the main task of humans throughout history (Lee \& Narjoko, 2015), it is no longer just for creating value to benefit individuals, organizations, or societies but an activity that should create a smart future where people can enjoy the best quality of life possible (Lee \& Trimi, 2018). Continuous innovation efforts have been identified as a spring board to propel economic development. All major revolutionary waves of human history - agriculture, industry, information, and now convergence - are all about innovation for creating new and better value (Lee, Olson, \& Trimi, 2012). Innovation has taken center stage as a major driver of economic growth - be it through incremental or radical innovation. Unfortunately, the status quo of most developing countries is to catch up with the developed world in virtually all aspects of their economies. Innovation in such economies is also at a stage of catching up, meanwhile such countries still find themselves having to adopt ideas and technologies that are obsolete in the developed world.

The purpose of this study is to make a case for an integrated approach to the innovation process in developing countries. Such an approach will involve public policy direction to deploy technology infrastructure, government's support for research and development (R\&D), public-private collaboration, university-industry research collaboration, and putting the expertise of scientists and engineers to use in R\&D. Such a multi-faceted approach can be very helpful in ensuring the discovery and use of new knowledge to push the innovation agenda. Much research has been done on R\&D and Information and communications technology (ICT) and their role in promoting innovation. Other dimensions have been explored extant literature, but the position of this paper is to examine the behavior of innovation at country level when these activities are combined.

$\mathrm{R} \& \mathrm{D}$ and ICT have been touted as the main drivers of innovation. Many researchers have emphasized that R\&D plays a major role in boosting innovation and hence productivity (Gërguri- Rashiti et al., 2017; Chen, 
Dai, \& Li, 2019; Kim, Hoi, Tuan, \& Trung, 2019). Other scholars have highlighted the role of ICT in the innovation process, making strong arguments that ICT is a significant driver of innovation (Kretschmer, 2012; Hue, 2019; Idota, Bunno, \& Tsuji, 2020). However, literature seldom considers the role of ICT next to R\&D (Mohnen, Polder, \& van Leeuwen, 2018). Venturini (2015) posits that both ICT and R\&D have positive but independent effects on Total Factor Productivity (TFP), while Corrado, Haskel, \& JonaLasinio (2017) argue that there is a relationship between ICT, R\&D and innovation activities. The argument can be expanded to include other important factors and activities that aid the innovation process. The role of research institutions has been seen as a critical tool to developing innovation activities (Minh \& Hjorts $\varnothing$, 2015; Cheah \& Yu, 2016). Government support for universities encourages them to get more actively involved in innovation activities (Huang \& Chen, 2017; Intarakumnerd \& Goto, 2018). Zhao \& Sui (2018) advocate for government support for private universities as well, in order to expand their scope of research and hence innovation.

Moreover, government intervention can be very critical in the area of technology deployment (Dodgson, 2018). Considering that most businesses that lead the innovation effort in developing countries are small and medium enterprises, the required technology infrastructure can be out of their reach. Shortcomings in infrastructure such as research facilities, telecommunications, internet connections, electricity and transportation deployed at the national level can aid innovation among business entities. It is also possible that government's intervention in the innovation effort can involve not just giving subsidies to businesses but also a conscious collaboration with the private sector (Amoroso, 2017). Li, Zhan, de Jong, \& Lukszo (2016) found that government-private sector collaboration fosters innovation and reduces government expenditure on service provision. Furthermore, this integrated approach can be holistic if the expertise of scientists and engineers is made available to benefit industry in research and development. Chul Lee, Park, \& Kang (2018) argue strongly that R\&D is positively influenced by scientific knowledge, such expertise can be very useful throughout the innovation process.

Research on the various factors that influence innovation is rife in developed economies, and much of extant literature is limited to single-country studies (Marsh, Rincon-Aznar, Vecchi, \& Venturini, 2017). The present study enhances literature by (i) analyzing a varied number of factors and how their integration can affect innovation. (ii) The study covers 43 developing countries in a bid to do a comprehensive analysis of this subject so that it will be useful for policy makers and academic researchers, and (iii) a vector autoregressive model is used as an analytical method to analyze how the various factors influence each other in the innovation process.

The study considers factors affecting innovation drawn from the $12^{\text {th }}$ pillar of the Global Competitiveness Report (GCR) published yearly by the World Economic Forum. The factors include; capacity for innovation, research institutions, collaborative R\&D between industry and universities, procurement of technology by government, and availability of persons with scientific and engineering knowledge. A thorough analysis of the role of these factors is done using panel vector auto-regression (PVAR) and granger causality models. We find that developing countries can improve upon innovation output if all the variables under study are pooled and integrated as a policy direction. Useful policy recommendations are made in this study for developing countries to improve upon their innovation activities.

The rest of this article is subsequently organized as follows: section 2 is an explanation of the methodology where we explain the econometric approach used in the study, followed by section 3 which contains the analysis of data. Sections 4 and 5 deal with discussions and conclusions respectively.

\section{Materials and Methods}

To achieve the objective of this study, we use the panel VAR model to analyze the various factors that contribute to enhancing innovation in developing countries. To analyze this model effectively, we first analyze the stationarity of the data by testing for unit root. Further, we test for granger causality and impulse response of innovation in relation to all other variables.

\subsection{Sampling and Data}

The data for this study comes from the $12^{\text {th }}$ pillar of the GCR which captures information on the level of innovation at country level. The factors captured as influencing innovation are indicated in Table 1. Each of these factors is given a score out of a maximum 7 points. This makes the analysis scientific and consistent 
since all factors are rated on the same score, moreover, overall scores on innovation for each country is also a maximum of 7 points, thus making the score for all countries consistent.

The sample includes a total of 43 countries that are ranked among the bottom 50 countries in the Global Innovation Index (2018). Among these 50, seven countries were dropped due to missing data for some of the years as captured in the GRC, an inclusion of such countries will make the panel unbalanced, and an analysis of this nature needs a strongly balanced panel to produce effective results. The data covers a ten year period from the 2008/2009 (captured as 2009 report in this study) up to 2017/2018 (captured as 2018 report). The main reason for the choice of this time period is that of consistency, over the years the methodology and nature of the report has gone through a lot of phases, the most recent one being in 2009. According to the World Economic Forum, a group of professors were consulted to improve upon the report (GCR, 2009). Inputs to innovation on the pillar 12 of the report especially, have been very consistent from the 2009 report to date. Table contains details of variables used in this study.

\section{Table 1: Variables for the study}

\begin{tabular}{|c|c|c|}
\hline Variable & Variable in data source & Definition \\
\hline INNOV & Innovation & $\begin{array}{l}\text { Creative ideas that result in new products and } \\
\text { processes }\end{array}$ \\
\hline Innov.cap. & Innovation Capacity & $\begin{array}{l}\text { The ability of a country to continually create new } \\
\text { processes and products }\end{array}$ \\
\hline Res. Inst. & $\begin{array}{l}\text { Quality of scientific } \\
\text { research institutions }\end{array}$ & $\begin{array}{l}\text { These institutions include universities and other } \\
\text { centers of research set up to research into specific } \\
\text { areas of national interest. }\end{array}$ \\
\hline$R \& D$ & $\begin{array}{l}\text { Investment in research and } \\
\text { development }\end{array}$ & Amount of investments in $R \& D$ \\
\hline Collab & $\begin{array}{l}\text { University-industry } \\
\text { research collaboration }\end{array}$ & $\begin{array}{l}\text { The extent to which universities partner with } \\
\text { industry to research and discover new product ideas }\end{array}$ \\
\hline Govt.IT & $\begin{array}{l}\text { Procurement of technology } \\
\text { products by the } \\
\text { government }\end{array}$ & $\begin{array}{l}\text { The extent of government investment in deploying } \\
\text { technology infrastructure for the country. }\end{array}$ \\
\hline Scient. \& Eng. & $\begin{array}{l}\text { Science and Engineering } \\
\text { experts }\end{array}$ & $\begin{array}{l}\text { Persons with proven expertise in the areas of science } \\
\text { and engineering, whose knowledge is beneficial } \\
\text { innovation }\end{array}$ \\
\hline
\end{tabular}

\section{Source: Global competitiveness report}

\subsection{Descriptive statistics}

In order to understand the characteristics of the data we are dealing with, we run the summary statistics to view a description of it as shown in Table 2 . The maximum score of innovation in the countries under study is 4.00 out of a possible score of 7.00, with a standard deviation of 0.35 , indicating that a good number of developing countries still have a lot to do in their innovation efforts. Prominent variables in the innovation effort include innovation capacity, collaborative research and availability of scientists and engineers, all with a maximum scorer of at least 5.00. Innovation output which is the ultimate goal remains the variable with the least score. 
Table 2: Descriptive statistics of data

\begin{tabular}{|c|c|c|c|c|c|}
\hline Variable & Obs & Mean & Std. dev. & Min & Max \\
\hline INNOV & 429 & 3.01 & 0.35 & 2.00 & 4.00 \\
\hline Innov. Cap. & 430 & 3.25 & 0.65 & 1.90 & 5.40 \\
\hline Res. Inst. & 430 & 3.31 & 0.55 & 1.80 & 4.70 \\
\hline R\&D & 430 & 2.95 & 0.42 & 1.80 & 4.40 \\
\hline Collab & 430 & 3.20 & 0.49 & 1.90 & 5.00 \\
\hline Govt.IT & 430 & 3.35 & 0.53 & 2.00 & 4.60 \\
\hline Scient.\& $\boldsymbol{E}$. $\boldsymbol{~}$ & 430 & 3.75 & 0.57 & 1.40 & 5.30 \\
\hline
\end{tabular}

\subsection{Panel Vector Auto-regressive (PVAR) Model}

PVARs are used to examine the extent of dynamic heterogeneity and of convergence clubs (Canova, 2004), to endogenously group units or to characterize their differences. VAR models have been commonly used in time-series contexts over the years, and recently several studies have adopted them in analyzing panel data. An advantage of VAR models is that we can analyze interactions of several variables, sometimes together with impulse response analysis. Since (Holtz-Eakin, Newey, \& Rosen, 1988) proposed PVAR models using instrumental variables (IVs) based estimation, several studies have used VARs. While there are several approaches to testing for Granger causality, the VAR model can be used to test the granger causality and impulse response analysis of innovation. Our study is consistent with Cao \& Sun (2011) who proved that a test of impulse response functions (IRFs) is possible with small $\mathrm{T}$ and large $\mathrm{N}$.

In Vector Auto-regressive (VAR) models all variables are treated as endogenous and interdependent, although in some relevant cases, exogenous variables could be included (Canova \& Ciccarelli, 2013). Hence a panel VAR model is constructed as follows:

$$
Y_{i t}=A_{0}(t)+A(\ell) Y_{i t-1}+u_{i t} \quad i=1, \ldots, N t=1, \ldots, T
$$

Where $Y_{i t}$ is a $G \times 1$ vector of endogenous variables? $A_{i t}(\ell)$ Are the coefficients on the lag endogenous variables $Y_{i t-1}$, and $u_{i t}$ is a $M \times 1$ vector of random disturbance.

Following equation 1, the PVAR equations are written as follows:

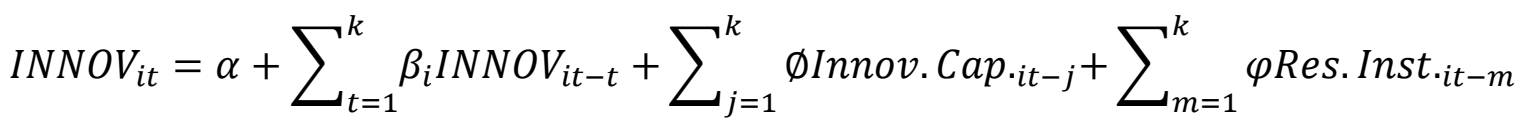

$$
\begin{aligned}
& +\sum_{p=1}^{k} \partial R \& D_{i t-p}+\sum_{r=1}^{k} \vartheta C O L L A B_{i t-r}+\sum_{s=1}^{k} \delta G o v . I T_{i t-s} \\
& +\sum_{q=1}^{k} \omega \text { Scient. \&Eng.it-q} u_{i t}
\end{aligned}
$$

Innov. Cap $_{i t}=\alpha$

$$
\begin{aligned}
& +\sum_{t=1}^{k} \beta_{i} \text { INNOV }_{i t-t}+\sum_{j=1}^{k} \text { ØInnov.Cap } \text {. } i t-j+\sum_{m=1}^{k} \varphi \text { Res. Inst }_{\text {it }-m} \\
& +\sum_{p=1}^{k} \partial R \& D_{i t-p}+\sum_{r=1}^{k} \vartheta C O L L A B_{i t-r}+\sum_{s=1}^{k} \delta G o v . I T_{i t-s} \\
& +\sum_{q=1}^{k} \omega \text { Scient.\&Eng.it-q}+u_{i t}
\end{aligned}
$$




$$
\begin{aligned}
& \text { Res. Inst. }_{. i t}=\alpha \\
& +\sum_{t=1}^{k} \beta_{i} \text { INNOV }_{i t-t}+\sum_{j=1}^{k} \text { IInnov.Cap } \cdot i t-j+\sum_{m=1}^{k} \varphi \text { Res. Inst. } i t-m \\
& +\sum_{p=1}^{k} \partial R \& D_{i t-p}+\sum_{r=1}^{k} \vartheta \operatorname{COLLAB} B_{i t-r}+\sum_{s=1}^{k} \delta G o v . I T_{i t-s} \\
& +\sum_{q=1}^{k} \omega \text { Scient. \&Eng.it-q}{ }+u_{i t} \\
& R \& D_{i t}=\alpha+\sum_{t=1}^{k} \beta_{i} \text { INNOV }_{i t-t}+\sum_{j=1}^{k} \emptyset \text { Innov.Cap } \cdot i t-j+\sum_{m=1}^{k} \varphi \text { Res. Inst }_{\cdot i t-m} \\
& +\sum_{p=1}^{k} \partial R \& D_{i t-p}+\sum_{r=1}^{k} \vartheta \operatorname{COLLAB} B_{i t-r}+\sum_{s=1}^{k} \delta G o v . I T_{i t-s} \\
& +\sum_{q=1}^{k} \omega \text { Scient.\&Eng.it-q}{ }_{i t}
\end{aligned}
$$

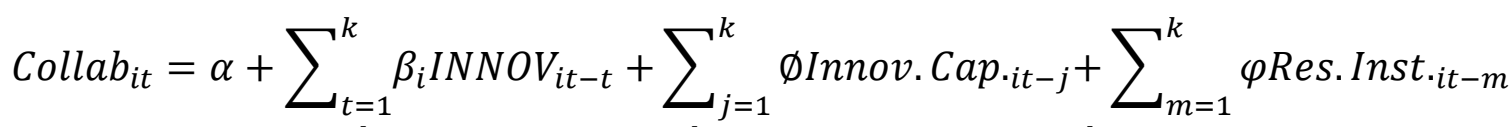$$
+\sum_{p=1}^{k} \partial R \& D_{i t-p}+\sum_{r=1}^{k} \vartheta \operatorname{COLLAB} B_{i t-r}+\sum_{s=1}^{k} \delta G o v \cdot I T_{i t-s}
$$$$
+\sum_{q=1}^{k} \omega \text { Scient.\&Eng.it-q}+u_{i t}
$$

$$
\begin{aligned}
& \text { Gov.IT }_{i t}=\alpha+\sum_{t=1}^{k} \beta_{i} \text { INNOV }_{i t-t}+\sum_{j=1}^{k} \text { ØInnov.Cap }{ }_{i t-j}+\sum_{m=1}^{k} \varphi \text { Res. Inst }_{\cdot i t-m} \\
& +\sum_{p=1}^{k} \partial R \& D_{i t-p}+\sum_{r=1}^{k} \vartheta \operatorname{COLLAB} B_{i t-r}+\sum_{s=1}^{k} \delta G o v \cdot I T_{i t-s} \\
& +\sum_{q=1}^{k} \omega \text { Scient.\&Eng.it-q}+u_{i t}
\end{aligned}
$$

Scient.\&Eng.it

$$
\begin{aligned}
& =\alpha \\
& +\sum_{t=1}^{k} \beta_{i} \text { INNOV }_{i t-t}+\sum_{j=1}^{k} \text { ØInnov.Cap }{ }_{i t-j}+\sum_{m=1}^{k} \varphi \text { Res. Inst }_{\cdot i t-m} \\
& +\sum_{p=1}^{k} \partial R \& D_{i t-p}+\sum_{r=1}^{k} \vartheta C O L L A B_{i t-r}+\sum_{s=1}^{k} \delta G o v . I T_{i t-s} \\
& +\sum_{q=1}^{k} \omega \text { Scient.\&Eng } \cdot i t-q+u_{i t}
\end{aligned}
$$

The estimation of the PVAR is done using ordinary least squares, and to determine the stability of our model, we do an inverse root test of the variables. To further our understanding of the interrelationship that exists among the variables, we do a granger causality analysis using the VAR. The ultimate objective is to determine if the variables together granger cause innovation in developing countries. A deeper understanding of the influence of the individual variables on innovation is necessary, therefore we do a variance decomposition of the data to achieve this objective.

\subsection{Impulse Response Function Test}

Impulse response function (IRF) is the output of a system when it is presented with a brief input signal. Impulse response analysis has been used widely in a time-series data analysis. However, it is also being increasingly used in panel data settings. Following Cao \& Sun (2011), we derive the asymptotic distribution of generalized IRF with a small $\mathrm{T}$ and large $\mathrm{N}$. 


\section{Data Analysis and Results}

\subsection{Unit root analysis}

The rationale for testing data for stationarity is to be sure that there is no form of shock that would throw the series out of its long-term equilibrium. The granger causality test also requires the variables to be stationary. We test for non-stationarity by using the Im-Pesaran-Shin (IPS), the Augmented Dickey Fuller (ADF) and the Phillips and Perron (PP) tests. Results of the stationarity as shown in Table 3 show that all the variables are integrated at first difference, with all three tests yielding consistent results. This form of stationarity gives the basis for the use of a VAR model to test the relationships among the variables.

Table 3: Result of Unit Root test

\begin{tabular}{|c|l|l|l|l|l|l|c|}
\hline \multicolumn{4}{|c|}{ At levels } & \multicolumn{3}{c|}{ At first difference } & \\
\hline Variables & IPS & ADF & PP & IPS & ADF & PP & $\begin{array}{c}\text { Order of } \\
\text { integration }\end{array}$ \\
\hline INNOV & 0.22 & 86.81 & 71.57 & $-8.67^{* *}$ & $247.40^{* *}$ & $290.06^{* *}$ & $I(1)$ \\
\hline Innov. Cap. & 3.55 & 40.53 & 21.90 & $-6.20^{* *}$ & $197.51^{* *}$ & $227.09^{* *}$ & $I(1)$ \\
\hline Res.Inst. & 3.75 & 59.29 & 50.10 & $-11.1^{* *}$ & $294.01^{* *}$ & $287.87^{* *}$ & $I(1)$ \\
\hline R\&D & 2.60 & 38.87 & 22.02 & $-8.80^{* *}$ & $250.77^{* *}$ & $267.04^{* *}$ & $I(1)$ \\
\hline Collab. & 5.14 & 74.44 & 86.15 & $-8.54^{* *}$ & $244.25^{* *}$ & $237.36^{* *}$ & $I(1)$ \\
\hline Gov. IT & 3.35 & 38.75 & 14.36 & $-11.50^{* *}$ & $281.37^{* *}$ & $267.67^{* *}$ & $I(1)$ \\
\hline Scient. \& Eng. & 3.72 & 49.17 & 60.29 & $-9.36^{* *}$ & $258.75^{* *}$ & $330.63^{* *}$ & $I(1)$ \\
\hline
\end{tabular}

Note: ** denotes a rejection of the null hypothesis of non-stationarity at 0.05 p-values

\subsection{Panel Vector-autoregressive (PVAR) test.}

All variables were run on the PVAR model. The lagged value of each variable is run to establish a causal relationship among all variables; results are shown in Table 4. The Durbin Watson (DW) values shown in the table indicate that there are no concerns of autocorrelation in the data set, each variable tested produced a DW value very close to 2 . A further test of the stability of our model using the inverse root test (as in figure 1) shows the model is stable since all roots lie within the unit circle with modulus less than 1.

$\mathrm{R} \& \mathrm{D}$ and government procurement of advanced technologies strongly influence the variation in innovation, contributing up to 5\% and 3\% increase in innovation respectively for a percentage increase in each of them. The other variables also influence on innovation but indirectly. R\&D which is a major influencer of innovation is positively affected by the quality of a country's research institutions and the level of collaborative research. A percentage increase in each of these two variables increases R\&D by up to $4.6 \%$ and $6.9 \%$ respectively. A percentage increase in government procurement of technology significantly increases a country's innovation capacity by $1.4 \%$ and R\&D by $7.1 \%$. Innovation capacity also significantly improves the quality of research institutions and collaborative research. Apart from its strong influence on innovation, R\&D also proves to be very vital to the quality of research institutions and collaborative research, perhaps a reciprocal relationship that shows the importance of investments in R\&D in improving other aspects of the innovation effort. From every aspect, these seven variables interrelate and influence each other significantly. 
Table 4: Results of PVAR test

\begin{tabular}{|c|c|c|c|c|c|c|c|c|c|}
\hline Variable & INNOV $_{t-1}$ & $\begin{array}{l}\text { Innov. } \\
\text { Cap.t-1 }\end{array}$ & Res. Inst.t-1 $_{\text {. }}$ & $R \& D_{t-1}$ & $\begin{array}{l}\text { COLLAB } \\
t-1\end{array}$ & Govt. IT ${ }_{t-1}$ & $\begin{array}{l}\text { Scient. } \\
\text { \&Eng. } t-1\end{array}$ & DW & $\begin{array}{l}\text { Adj. } \\
\mathbf{R}^{2}\end{array}$ \\
\hline INNOV & $\begin{array}{l}0.6145 * * * \\
(0.0589)\end{array}$ & $\begin{array}{c}0.0407 \\
(0.0507)\end{array}$ & $\begin{array}{c}0.0898 \\
(0.0610)\end{array}$ & $\begin{array}{l}0.0509 * * * \\
(0.0100)\end{array}$ & $\begin{array}{l}0.0662 \\
(0.0618)\end{array}$ & $\begin{array}{c}0.0311^{*} \\
(0.0519)\end{array}$ & $\begin{array}{c}0.0322 \\
(0.0428)\end{array}$ & 2.284 & 0.49 \\
\hline $\begin{array}{l}\text { Innov. } \\
\text { Cap. }\end{array}$ & $\begin{array}{c}-0.007 \\
(0.0732)\end{array}$ & $\begin{array}{l}0.0404 \\
(0.0630)\end{array}$ & $\begin{array}{l}0.1297 * \\
(0.0758)\end{array}$ & $\begin{array}{c}0.1197 \\
(0.0915)\end{array}$ & $\begin{array}{l}0.1383^{*} \\
(0.0768)\end{array}$ & $\begin{array}{l}0.0536 \\
(0.0644)\end{array}$ & $\begin{array}{c}0.1069 * \\
(0.0532)\end{array}$ & 1.872 & 0.28 \\
\hline Res. Inst. & $\begin{array}{l}-0.0660 \\
(0.0567)\end{array}$ & $\begin{array}{c}0.0575 \\
(0.0487)\end{array}$ & $\begin{array}{l}0.8290 * * * \\
(0.0587)\end{array}$ & $\begin{array}{c}0.0909 \\
(0.0708)\end{array}$ & $\begin{array}{l}0.0546 * * * \\
(0.0004)\end{array}$ & $\begin{array}{c}0.0865^{*} \\
(0.0399)\end{array}$ & $\begin{array}{c}0.0273 \\
(0.0412)\end{array}$ & 1.917 & 0.31 \\
\hline R\&D & $\begin{array}{l}-0.0244 \\
(0.0548)\end{array}$ & $\begin{array}{l}-0.0510 \\
(0.0471)\end{array}$ & $\begin{array}{r}0.0463 * \\
(0.0067)\end{array}$ & $\begin{array}{l}0.8107 * * * \\
(0.0685)\end{array}$ & $\begin{array}{l}0.0690^{*} \\
(0.0275)\end{array}$ & $\begin{array}{l}0.0536 \\
(0.0482)\end{array}$ & $\begin{array}{c}0.0170 \\
(0.0398)\end{array}$ & 1.866 & 0.21 \\
\hline COLLAB & $\begin{array}{l}-0.0774 \\
(0.0646)\end{array}$ & $\begin{array}{l}-0.0179 \\
(0.0556)\end{array}$ & $\begin{array}{c}0.1164 * \\
(0.0669)\end{array}$ & $\begin{array}{l}0.1535^{*} \\
(0.0807)\end{array}$ & $\begin{array}{l}0.6714 * * * \\
(0.0678)\end{array}$ & $\begin{array}{l}0.1228 * * \\
(0.0569)\end{array}$ & $\begin{array}{l}-0.0509 \\
(0.0470)\end{array}$ & 1.887 & 0.28 \\
\hline Gov. IT & $\begin{array}{c}0.0077 \\
(0.0729)\end{array}$ & $\begin{array}{l}0.0149 * \\
* \\
(0.0027)\end{array}$ & $\begin{array}{l}0.0461 \\
(0.0754)\end{array}$ & $\begin{array}{l}0.0719 * * \\
(0.0910)\end{array}$ & $\begin{array}{l}-0.1046 \\
(0.0764)\end{array}$ & $\begin{array}{l}0.8093 * * * \\
(0.0641)\end{array}$ & $\begin{array}{c}0.0523 \\
(0.0530)\end{array}$ & 2.002 & 0.45 \\
\hline $\begin{array}{c}\text { Scient. \& } \\
\text { Eng. }\end{array}$ & $\begin{array}{c}0.0601 \\
(0.0751)\end{array}$ & $\begin{array}{c}0.0554 \\
(0.0646)\end{array}$ & $\begin{array}{l}0.0275 \\
(0.0778)\end{array}$ & $\begin{array}{l}-0.0198 \\
(0.0938)\end{array}$ & $\begin{array}{l}-0.0299 \\
(0.0788)\end{array}$ & $\begin{array}{c}0.1242 * \\
(0.0661)\end{array}$ & $\begin{array}{l}0.5925 * * * \\
(0.0546)\end{array}$ & 2.175 & 0.43 \\
\hline
\end{tabular}

Note: $* * *, * *$ and $*$ denote $1 \%, 5 \%$ and $10 \%$ significance levels respectively. Parentheses contain the standard errors.

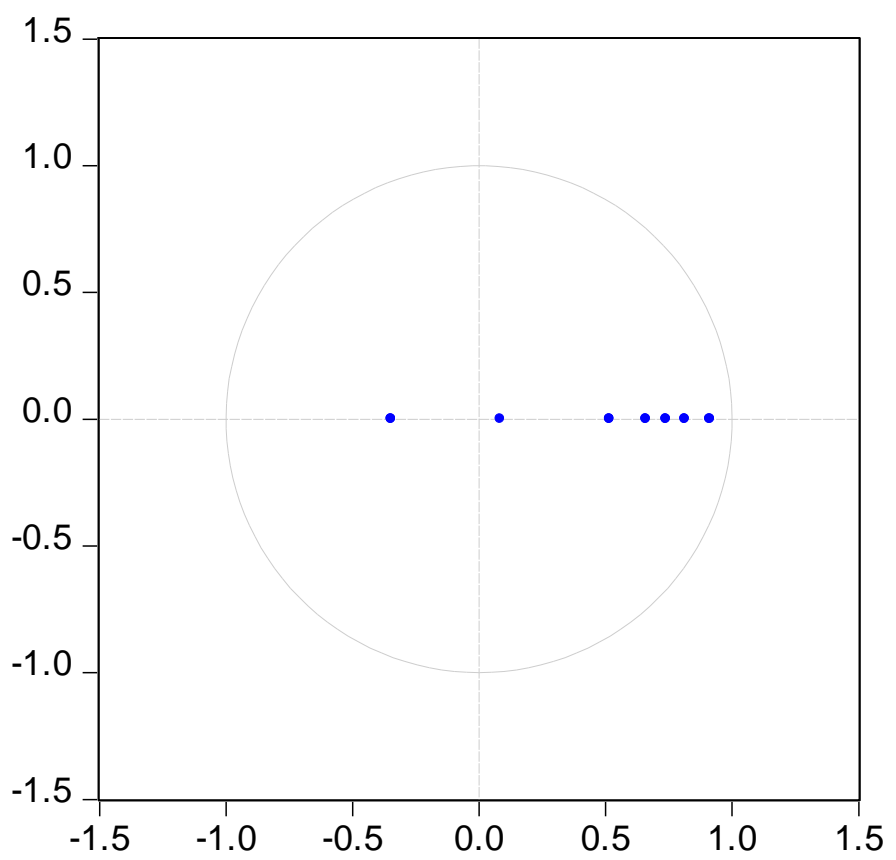

Figure 1: Test of model stability

\subsection{VAR Granger Causality Test}

Granger causality is an idea of causality that has been employed in statistics, econometrics, machine learning and data mining. The main argument is that time series $a$ is a potential cause of time series $b$, if $a$ significantly helps improve the prediction of the future values of $b$ (Lozano, Sattigeri, Mojsilović, \& Varshney, 2016). Thus, we determine if the values of the other variables have any causal effect on innovation. Results of a granger causality test in Table 5 show similar information to those of the PVAR 
test. Innovation capacity, R\&D and government procurement of advanced technology all granger cause innovation at country level, and all the variables together granger cause innovation. Interestingly, innovation granger causes the quality of research institutions in a country, this could be influenced by learning curves in innovation and the potential of new ideas to improve upon institutional capacity.

Table 5: Granger causality test

\begin{tabular}{|l|l|l|l|l|}
\hline Null hypothesis & Chi square & df & P-value & Outcome \\
\hline Innov. Cap. does not granger cause INNOV & 15.46530 & 2 & 0.0004 & Reject \\
\hline INNOV does not granger cause Innov. Cap & 0.100491 & 2 & 0.9510 & Accept \\
\hline Res. Inst. do not granger cause INNOV & 3.771667 & 2 & 0.1517 & Accept \\
\hline INNOV does not granger cause Res. Inst. & 6.029174 & 2 & 0.0491 & Reject \\
\hline R\&D does not granger cause INNOV & 9.340666 & 2 & 0.0094 & Reject \\
\hline INNOV does not granger cause R\&D & 0.843466 & 2 & 0.6559 & Accept \\
\hline COLLAB does not granger cause INNOV & 1.252288 & 2 & 1.2522 & Accept \\
\hline INNOV does not granger cause COLLAB & 2.045265 & 2 & 0.3596 & Accept \\
\hline Govt. IT does not granger cause INNOV & 5.151861 & 2 & 0.0761 & Reject \\
\hline INNOV does not granger cause Gov. IT & 0.019861 & 2 & 0.9901 & Accept \\
\hline Scient. \& Eng. does not granger cause INNOV & 0.572803 & 2 & 0.7510 & Accept \\
\hline INNOV does not granger cause Scient. \& Eng. & 0.664375 & 2 & 0.7174 & Accept \\
\hline All variables together do not granger cause INNOV & 56.00272 & 12 & 0.0000 & Reject \\
\hline
\end{tabular}

\subsection{Variance Decomposition Test}

In order to further understand how these factors relate with each other and especially innovation, we do a variance decomposition test. The results are shown in Table 6 below. The evidence of interdependencies also shows up, we can observe some variables impacting the variance in other variables. Research institutions and R\&D will contribute greatly to innovation in the long-run. Innovation capacity and government procurement of technology products will also exert a significant influence on innovation. It is also evident that innovation and collaborative research have an effect on the quality of research institutions, an indication that the more innovation these institutions get involved in, the more effective they become in the process. Frequent partnership with industry in research and development also helps to strengthen the ability and expertise of research institutions. Innovation and collaboration also improves a country's innovation capability and its $R \& D$ activities, obviously because these activities are interrelated and interact in the whole process of innovation. Similar interactions can be seen between and research institutions and government procurement of advanced technology. These interrelations point to the fact that factors considered in this study are all directly and indirectly influencing innovation in developing countries. 
Table 6: Variance decomposition test using Cholesky (d.f. adjusted) factors

\begin{tabular}{|c|c|c|c|c|c|c|c|c|}
\hline Variable & Period & INNOV & Innov. Cap. & Res. Inst. & R\&D & COLLAB & Gov. IT & Scient. \& Eng. \\
\hline \multirow[t]{5}{*}{ INNOV } & 1 & 100.000 & 0.000 & 0.000 & 0.000 & 0.000 & 0.000 & 0.000 \\
\hline & 5 & 89.568 & 1.943 & 2.020 & 4.418 & 0.716 & 1.111 & 0.222 \\
\hline & 10 & 89.349 & 1.985 & 2.093 & 4.484 & 0.719 & 1.136 & 0.230 \\
\hline & 15 & 89.307 & 1.989 & 2.110 & 4.486 & 0.722 & 1.143 & 0.240 \\
\hline & 20 & 89.291 & 1.990 & 2.117 & 4.485 & 0.722 & 1.145 & 0.246 \\
\hline \multirow[t]{5}{*}{ Innov. Cap. } & 1 & 13.719 & 86.280 & 0.000 & 0.000 & 0.000 & 0.000 & 0.000 \\
\hline & 5 & 12.714 & 79.540 & 1.993 & 0.558 & 3.374 & 0.715 & 1.103 \\
\hline & 10 & 12.663 & 79.129 & 2.132 & 0.576 & 3.423 & 0.744 & 1.330 \\
\hline & 15 & 12.653 & 79.049 & 2.142 & 0.590 & 3.419 & 0.743 & 1.400 \\
\hline & 20 & 12.652 & 79.028 & 2.147 & 0.593 & 3.419 & 0.743 & 1.416 \\
\hline \multirow[t]{5}{*}{ Res. Inst. } & 1 & 13.943 & 9.650 & 76.406 & 0.000 & 0.000 & 0.000 & 0.000 \\
\hline & 5 & 16.073 & 15.333 & 60.830 & 1.390 & 3.8390 & 0.856 & 1.676 \\
\hline & 10 & 16.811 & 14.586 & 56.269 & 1.385 & 5.4864 & 1.288 & 4.172 \\
\hline & 15 & 17.066 & 14.165 & 54.627 & 1.389 & 5.7548 & 1.511 & 5.485 \\
\hline & 20 & 17.150 & 13.985 & 53.965 & 1.378 & 5.7805 & 1.617 & 6.120 \\
\hline \multirow[t]{5}{*}{ R\&D } & 1 & 17.957 & 10.327 & 4.146 & 67.568 & 0.000 & 0.000 & 0.000 \\
\hline & 5 & 19.980 & 10.035 & 8.949 & 56.567 & 2.291 & 1.537 & 0.636 \\
\hline & 10 & 20.828 & 9.727 & 10.700 & 50.719 & 3.034 & 2.999 & 1.990 \\
\hline & 15 & 20.984 & 9.614 & 11.592 & 48.327 & 3.139 & 3.456 & 2.883 \\
\hline & 20 & 20.993 & 9.571 & 11.972 & 47.365 & 3.157 & 3.581 & 3.358 \\
\hline \multirow[t]{5}{*}{ COLLAB } & 1 & 14.119 & 2.742 & 3.155 & 7.2723 & 72.709 & 0.000 & 0.000 \\
\hline & 5 & 14.837 & 3.885 & 10.201 & 15.418 & 54.063 & 1.348 & 1.676 \\
\hline & 10 & 16.235 & 5.172 & 14.194 & 16.640 & 45.500 & 1.913 & 4.172 \\
\hline & 15 & 16.749 & 5.560 & 15.512 & 16.276 & 42.866 & 2.229 & 5.485 \\
\hline & 20 & 16.907 & 5.665 & 15.989 & 15.983 & 41.889 & 2.362 & 6.120 \\
\hline \multirow[t]{5}{*}{ Gov. IT } & 1 & 14.376 & 0.654 & 0.183 & 7.1715 & 5.466 & 72.146 & 0.000 \\
\hline & 5 & 15.221 & 0.398 & 2.578 & 13.080 & 2.604 & 65.735 & 0.381 \\
\hline & 10 & 16.291 & 0.914 & 4.535 & 13.243 & 2.161 & 61.107 & 1.449 \\
\hline & 15 & 16.548 & 1.128 & 5.687 & 12.844 & 2.083 & 59.336 & 2.371 \\
\hline & 20 & 16.599 & 1.205 & 6.021 & 12.656 & 2.069 & 58.610 & 2.837 \\
\hline \multirow[t]{5}{*}{ Scient. \& Eng. } & 1 & 2.401 & 0.523 & 0.379 & 0.172 & 0.031 & 0.563 & 95.927 \\
\hline & 5 & 6.036 & 0.379 & 2.018 & 0.184 & 0.123 & 3.106 & 88.149 \\
\hline & 10 & 6.833 & 0.626 & 3.888 & 0.411 & 0.128 & 3.703 & 84.408 \\
\hline & 15 & 7.090 & 0.763 & 4.756 & 0.513 & 0.125 & 3.830 & 82.763 \\
\hline & 20 & 7.194 & 0.829 & 5.123 & 0.538 & 0.132 & 3.845 & 82.335 \\
\hline
\end{tabular}




\subsection{Impulse Response Function (IRF) Test}

In the IRF test we try to test the response of innovation to a one-standard deviation shock to each of the input variables using the Cholesky degree of freedom adjusted. The results as in figure 2 show a similar response to shocks recorded in each of the input variables, the response function lies within $95 \%$ confidence level intervals and shows a sharp positive response in the short run and then normalize in the long run. In most cases there is a negative response between the second and fourth periods and by the sixth period it stabilizes through to the tenth period.

Response of innovation to innovation capacity

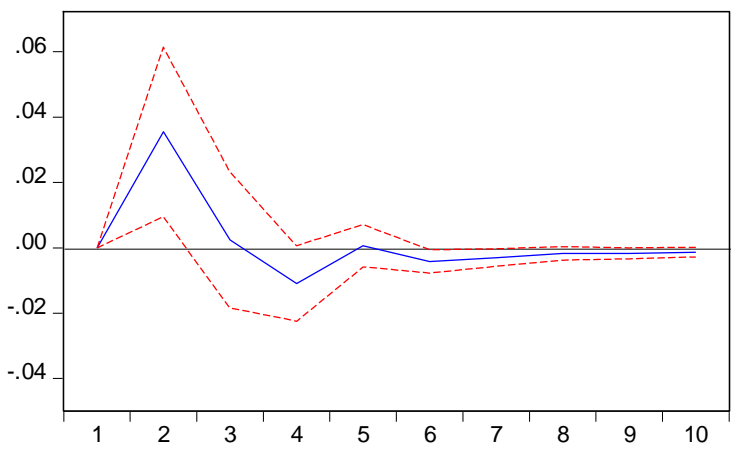

Response of innovation to $R \& D$

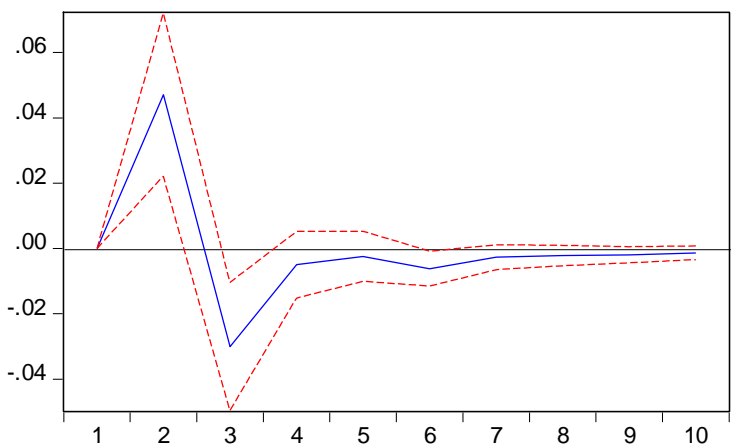

Response of innovation to quality of Res. Inst.

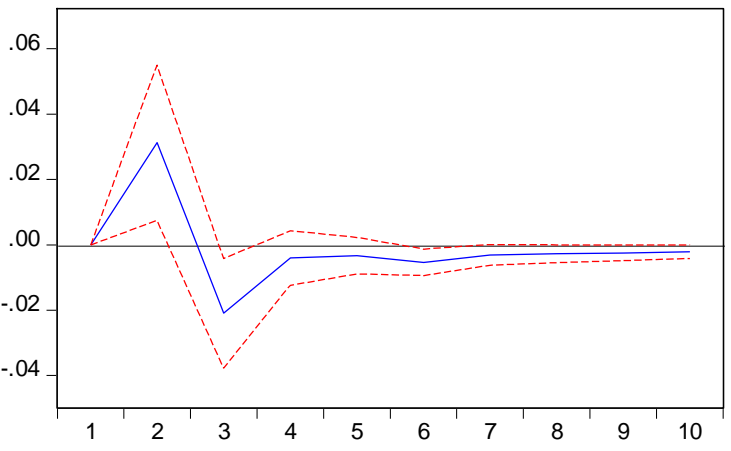

Response of innovation to collaborative research

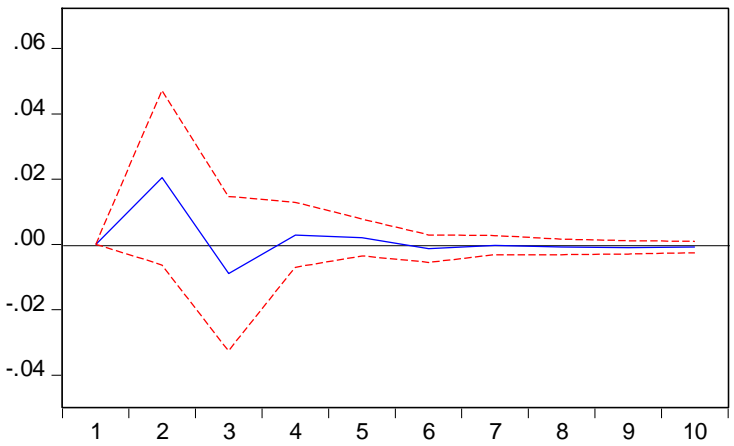

Response of innovation to Government procurement of technology Response of innovation to availability of scient, \& Eng.
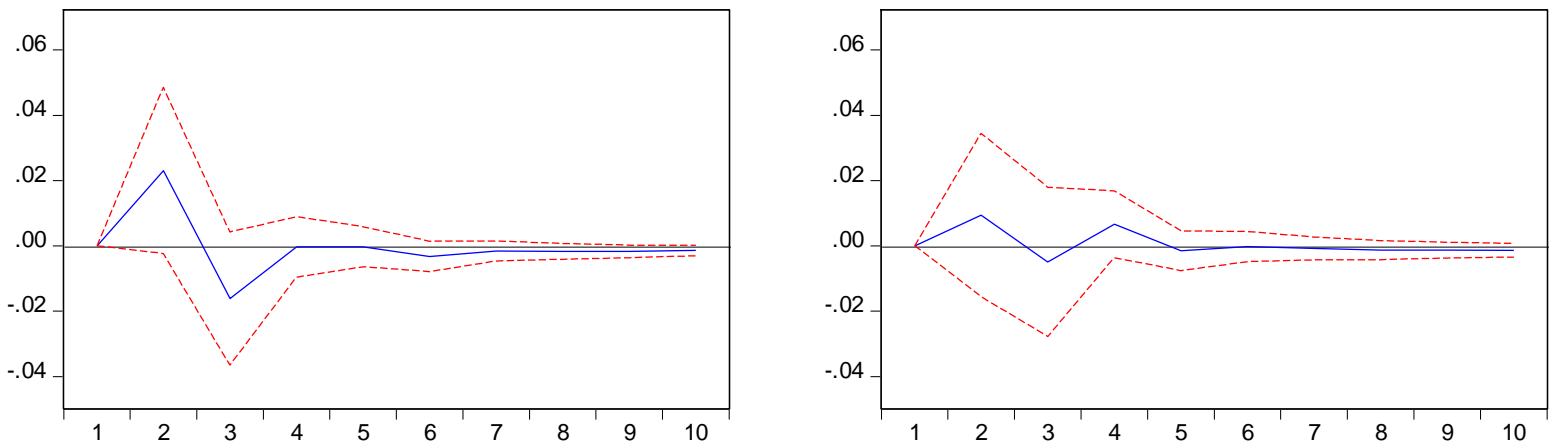

Figure 2: Response to Cholesky One S.D. (d.f. adjusted)

\section{Discussions}

Many factors have been highlighted as the critical tools for enhancing innovation including technological infrastructure, research institutions and investment in R\&D. Our findings are consistent with convention and most research findings that place the factors mentioned above at the center stage for shoring up innovation in developing countries. We find that innovation is strongly influenced by its past levels of intensity and growth. It is also worth noting the importance of other factors that influence the growth of innovation; R\&D is a very strong influencer of innovation as shown in this study. This finding is consistent with that of many other researchers in this field (Baumann \& Kritikos, 2016; Chen, Dai, \& Li, 2019; Wu, Harrigan, Ang, \& $\mathrm{Wu}, 2019)$. R\&D activities are hence very useful in shoring up innovation in developing countries. 
Moreover, $\mathrm{R} \& \mathrm{D}$ is found to be a major influencing factor for collaborative research between research institutions and industry. Interestingly, while we do not find R\&D to be directly influenced by ICT, the opposite is rather the case $-\mathrm{R} \& \mathrm{D}$ influences the deployment of technology infrastructure. This could be the situation in developing countries as the need for $\mathrm{R} \& \mathrm{D}$ is pushing governments to invest ICT. Investment in $\mathrm{R} \& \mathrm{D}$ has been noted to increase a country's competitive advantage, promote the international transfer of technological competences and intensify market competition, and thus contribute to the growth of the economy. We have also found the deployment of ICT infrastructure as a strong force to propel innovation. Direct government involvement in ICT systems at the national level proves to be a very important investment in the growth of innovation activities. ICT affects the quality of research institutions positively, university-industry research collaboration and the availability of scientists and engineers. These are all factors that affect innovation activities in developing countries, hence it is important for National Innovation Systems (NIS) to inculcate a policy for ICT infrastructure deployment at country level.

Contrary to findings by Ding et al. (2010) and Kleis, Chwelos, Ramirez, and Cockburn (2012), we find a weak relationship between ICT and R\&D, this is consistent with Mohnen, Polder, \& van Leeuwen (2018) who posit that there is a weak link between ICT and R\&D as inputs to innovation. This phenomenon could be due to the inability of developing countries to utilize the full economic value of ICT facilities at their disposal. There is a rather indirect link between these two factors, in that, while they may not be seen as complementary, ICT has a positive influence on university-industry research collaboration, which in turn has a positive impact on R\&D. This is also consistent with Zhu \& Jeon (2007) and Forman, Zeebroeck, and Forman (2012) who opine the investment in ICT facilitates knowledge spillovers and promotes R\&D collaborations.

A country's capacity to innovate is still a weak link in the innovation process. It is rather influenced by the quality of research institutions and collaborative research, the level of these activities build up a country's ability to innovate, however, there is limited evidence to show that an improved capacity to innovate necessarily leads to innovation at country level. Research institutions, including universities and other specialized research institutions play a critical role in innovation. Research institutions in this study is found to be a strong influencer of $R \& D$ and collaborative research. Lundvall (2007) notes that such institutions propel the activities of innovation in developed countries, we find in this study, a corroborative evidence with the above assertion for developing countries as well. The question remains whether developing countries are investing enough in and building the capacity of such institutions to push the innovation agenda.

In addition, university-industry collaborative research is also a strong factor influencing the innovation process. It has a significant and positive impact on the innovation capacity, research institutions, and R\&D. Collaborative research builds and sustains the capacity of industry to continuously innovate, it also builds up the capacity of these research institutions as well. Collaborative research complements, rather than replaces, R\&D by collaborating firms, and improves the performance of innovating firms (Hanel \& St-Pierre, 2006). Such collaborations can boost the innovation activities of companies and improve the originality of the inventions that industry churns out. Developing countries can benefit from this kind of arrangements, aimed at encouraging research institutions to collaborate with industry to research, discover and commercialize new products and ideas. China's economy for instance, has benefited from this form arrangement (TurriagoHoyos et al., 2015) since the government started introducing science and technology policies in the 1970s. These collaborative arrangements can be very beneficial to industry and the economic development of countries. Extant literature shows that research collaboration has played a crucial role in the advancement of knowledge through experimental research (Abbas et al, 2018).

Again, the availability of scientists and engineers in a country does not show strong evidence of it playing a critical role in the innovation process in this study. However, this variable has a positive impact on the capacity of a country to innovate. This phenomenon also buttresses the point that developing countries are not able to fully exploit the economic benefits of science and engineering expertise available. Egbetokun et al (2016) found a strong positive correlation between innovation and the level of education of managers, including higher academic degree and education in science or engineering. Similar findings are reported in studies of firms in other countries, including Ghana (Robson, Haugh, \& Obeng, 2009), Tanzania (Hall, Matos, Sheehan, \& Silvestre, 2012) and Uganda (Oyelaran-Oyeyinka \& Lal, 2006). Fu (2011) showed that 
in regions of China with more highly educated and skilled workers FDI spillovers are greater. The knowledge of scientists and engineers in developing countries is thus, an important factor in the innovation process.

\section{Conclusion and policy implications}

This study set out to make a strong case for an integrated approach to innovation in developing countries. Using data of 43 developing countries published by the Global Competitiveness Report (GCR), the factors espoused in the $12^{\text {th }}$ pillar of the GCR as affecting innovation include: capacity for innovation, research institutions, R\&D, collaborative research, procurement of technology by the government, and persons with science and engineering expertise. We use a panel vector auto-regression model to examine how these factors influence innovation. The study went further to conduct a granger causality test and variance decomposition with a focus on the main variable, innovation.

Innovation is found to be strongly influenced by $R \& D$ and government investment in technology infrastructure. Even though the other factors do not show a direct effect on innovation, they nevertheless have an indirect impact, in that; they have an influence on R\&D and ICT, which also influence the level of innovation of a country. Another important issue to note is that all the six variables put together have a significant and positive impact on innovation. $R \& D$ which is a major contributor to innovation is largely influenced by the quality of research institutions and university-industry collaborative research. Research institutions are found to play a critical role in the innovation process. A country's innovation capacity is directly linked with the availability of scientists and engineers with requisite expertise. However, it is obvious from this study that the economic value of science and engineering experts is not being fully utilized by developing countries, extant literature proves that such expertise are necessary for the diffusion and utilization of scientific knowledge.

Policy implications of this study buttress the main objective; the innovation process needs to be holistic, encompassing a variety of activities pulling together. First, governments in developing countries need to invest more in technology infrastructure and $\mathrm{R} \& \mathrm{D}$, this will push up innovation activities at firm level as well, since technology infrastructure serves as a platform for manufacturers to improve on their R\&D activities. Second, policies on innovation should inculcate deliberate efforts to improve upon the capacity of research institutions, and dedicate more resources for their R\&D activities. Third, efforts should also be made to foster collaborative research between industry and research institutions, this will help build up the capacity of industry. Fourth, authorities in developing countries should provide the requisite platforms for scientists and engineers to bring their knowledge to bear in the innovation process. This all-encompassing approach is an integration of all efforts to push up innovation in developing countries.

The major limitation of this study is the time period which spanned ten years. This limitation is due to the quest for complete and consistent data for all variables under study. Future studies should explore more data sources in order to extend the time period of the study, findings from such studies could provide more insight to the major drivers of innovation in developing economies.

\section{Conflict of interest}

The authors hereby declare no conflict of interest in this work.

Acknowledgment: This work is supported by the Social Science Funding Project of Jiangsu Province (No. 18GLB024)

\section{References}

[1.] Abbas, A., Avdic, A., Xiaobao, P., Hasan, M. M., \& Ming, W. (2018). University-government collaboration for the generation and commercialization of new knowledge for use in industry. Journal of Innovation \& Knowledge, 4(1), 23-31. https://doi.org/10.1016/j.jik.2018.03.002

[2.] Amoroso, S. (2017). Multilevel heterogeneity of R\&D cooperation and innovation determinants. Eurasian Business Review, 7(1), 93-120.

[3.] Baumann, J., \& Kritikos, A. S. (2016). The link between R\&D, innovation and productivity: Are micro firms different? Research Policy, 45(6), 1263-1274. https://doi.org/10.1016/j.respol.2016.03.008

[4.] Canova, F. (2004). Testing for convergence clubs in income per capita: a predictive density 
approach. International Economic Review, 45(1), 49-77.

[5.] Canova, F., \& Ciccarelli, M. (2013). Panel vector autoregressive models: A survey. Advances in Econometrics, 32(15), 205-246. https://doi.org/10.1108/S0731-9053(2013)0000031006

[6.] Cao, B., \& Sun, Y. (2011). Asymptotic distributions of impulse response functions in short panel vector autoregressions. Journal of Econometrics, 163(2), 127-143.

[7.] Cheah, S., \& Yu, C. (2016). Assessing economic impact of research and innovation originating from public research institutions and universities - case of Singapore PRIs. Triple Helix, 3(1), 6.

[8.] Chen, D., Dai, L., \& Li, D. (2019). A Delicate Balance for Innovation: Competition and Collaboration in R\&D Consortia. Management and Organization Review, 15(1), 145-176.

[9.] Corrado, C., Haskel, J., \& Jona-Lasinio, C. (2017). Knowledge spillovers, ICT and productivity growth. Oxford Bulletin of Economics and Statistics, 79(4), 592-618.

[10.] Dodgson, M. (2018). Technological collaboration in industry: strategy, policy and internationalization in innovation. Routledge.

[11.] Egbetokun, A., Atta-Ankomah, R., Jegede, O., \& Lorenz, E. (2016). Firm-level innovation in Africa: overcoming limits and constraints. Innovation and Development, 6(2), 161-174. https://doi.org/10.1080/2157930x.2016.1224619

[12.] Forman, C., Zeebroeck, N. Van, \& Forman, C. (2012). From Wires to Partners : How the Internet Has Fostered $R \& D$ Collaborations Within Firms From Wires to Partners : How the Internet Has Fostered $R \&$ D Collaborations Within Firms. (June 2014).

[13.] Fu, X. (2011). Indigenous and Foreign Innovation Efforts and Drivers of Technological Upgrading: Evidence from China. World Development, 39(7), 1213-1225. https://doi.org/10.1016/j.worlddev.2010.05.010

[14.] Gërguri-Rashiti, S., Ramadani, V., Abazi-Alili, H., Dana, L., \& Ratten, V. (2017). ICT, innovation and firm performance: the transition economies context. Thunderbird International Business Review, 59(1), 93-102.

[15.] Hall, J., Matos, S., Sheehan, L., \& Silvestre, B. (2012). Entrepreneurship and innovation at the base of the pyramid: a recipe for inclusive growth or social exclusion? Journal of Management Studies, 49(4), 785-812.

[16.] Hanel, P., \& St-Pierre, M. (2006). Industry-university collaboration by Canadian manufacturing firms. Journal of Technology Transfer, 31(4), 485-499. https://doi.org/10.1007/s 10961-006-00095

[17.] Holtz-Eakin, D., Newey, W., \& Rosen, H. S. (1988). Estimating vector autoregressions with panel data. Econometrica: Journal of the Econometric Society, 56, 1371-1395.

[18.] Huang, M.-H., \& Chen, D.-Z. (2017). How can academic innovation performance in universityindustry collaboration be improved? Technological Forecasting and Social Change, 123, 210-215.

[19.] Hue, T. T. (2019). The determinants of innovation in Vietnamese manufacturing firms: an empirical analysis using a technology-organization-environment framework. Eurasian Business Review, 9(3), 247-267.

[20.] Idota, H., Bunno, T., \& Tsuji, M. (2020). Impact of ICT on innovation: the case of Japanese SMEs. In Disruptive Technology: Concepts, Methodologies, Tools, and Applications (pp. 1624-1651). IGI Global.

[21.] Intarakumnerd, P., \& Goto, A. (2018). Role of public research institutes in national innovation systems in industrialized countries: The cases of Fraunhofer, NIST, CSIRO, AIST, and ITRI. Research Policy, 47(7), 1309-1320.

[22.] Kim, W. J., Hoi, T. V., Tuan, L. N., \& Trung, N. N. (2019). R\&D, training and accessibility to finance for innovation: a case of Vietnam, the country in transition. Asian Journal of Technology Innovation, 1-22.

[23.] Kleis, L., Chwelos, P., Ramirez, R. V, \& Cockburn, I. (2012). Information technology and intangible output: The impact of IT investment on innovation productivity. Information Systems Research, 23(1), 42-59.

[24.] Kretschmer, T. (2012). Information and communication technologies and productivity growth: A Survey of Literature. OECD iLibrary.

[25.] Lee, Cassey, \& Narjoko, D. (2015). Escaping the middle-income trap in Southeast Asia: Micro evidence on innovation, productivity, and globalization. Asian Economic Policy Review, 10(1). 
https://doi.org/10.1111/aepr.12090

[26.] Lee, Chul, Park, G., \& Kang, J. (2018). The impact of convergence between science and technology on innovation. The Journal of Technology Transfer, 43(2), 522-544.

[27.] Lee, S. M., Olson, D. L., \& Trimi, S. (2012). Innovative collaboration for value creation. Organizational Dynamics, 41(1), 7-12.

[28.] Lee, S. M., \& Trimi, S. (2018). Innovation for creating a smart future. Journal of Innovation \& Knowledge, 3(1), 1-8.

[29.] Li, Y., Zhan, C., de Jong, M., \& Lukszo, Z. (2016). Business innovation and government regulation for the promotion of electric vehicle use: lessons from Shenzhen, China. Journal of Cleaner Production, 134, 371-383.

[30.] Lozano, A. C., Sattigeri, P., Mojsilović, A., \& Varshney, K. R. (2016). Stable estimation of Granger-causal factors of country-level innovation. 2016 IEEE Global Conference on Signal and Information Processing (GlobalSIP), 1290-1294. IEEE.

[31.] Lundvall, B. (2007). National innovation systems-analytical concept and development tool. Industry and Innovation, 14(1), 95-119.

[32.] Marsh, I. W., Rincon-Aznar, A., Vecchi, M., \& Venturini, F. (2017). We see ICT spillovers everywhere but in the econometric evidence: a reassessment. Industrial and Corporate Change, 26(6), 1067-1088.

[33.] Minh, T. T., \& Hjorts $\varnothing$, C. N. (2015). How Institutions Influence SME Innovation and Networking Practices: The Case of V ietnamese Agribusiness. Journal of Small Business Management, 53, 209-228.

[34.] Mohnen, P., Polder, M., \& van Leeuwen, G. (2018). ICT, $R \& D$ and organizational innovation: exploring complementarities in investment and production. National Bureau of Economic Research.

[35.] Oyelaran-Oyeyinka, B., \& Lal, K. (2006). Learning new technologies by small and medium enterprises in developing countries. Technovation, 26(2), 220-231.

[36.] Robson, P. J. A., Haugh, H. M., \& Obeng, B. A. (2009). Entrepreneurship and innovation in Ghana: Enterprising Africa. Small Business Economics, 32(3), 331-350. https://doi.org/10.1007/s11187-008-9121-2

[37.] Turriago-Hoyos, A., Thoene, U., Bernal-Torres, C., \& Alfonso-Lizarazo, E. (2015). Product innovation, research and development and technology acquisition: A case study of the industrial sector in Colombia. Institutions and Economies, 7(2), 85-119.

[38.] Venturini, F. (2015). The modern drivers of productivity. Research Policy, 44(2), 357-369.

[39.] Wu, J., Harrigan, K. R., Ang, S. H., \& Wu, Z. (2019). The impact of imitation strategy and R\&D resources on incremental and radical innovation: evidence from Chinese manufacturing firms. The Journal of Technology Transfer, 44(1), 210-230.

[40.] Zhao, M., \& Sui, G. (2018). Research on the Construction Mechanism of Collaborative Innovation Research Platform of Private Universities. In Transactions on Edutainment XIV (pp. 183-193). Springer.

[41.] Zhu, L., \& Jeon, B. N. (2007). International R\&D spillovers: Trade, FDI, and information technology as spillover channels. Review of International Economics, 15(5), 955-976. 